\title{
Population and prey of the Bengal Tiger Panthera tigris tigris (Linnaeus, 1758) (Carnivora: Felidae) in the Sundarbans, Bangladesh
}

\author{
M. Monirul H. Khan
}

Department of Zoology, Jahangirnagar University, Savar, Dhaka 1342, Bangladesh

Email: mmhkhan@hotmail.com

Date of publication (online): 26 Febryary 2012 Date of publication (print): 26 February 2012 ISSN 0974-7907 (online) | 0974-7893 (print)

Editor: L.A.K. Singh

Manuscript details:

Ms \# 02666

Received 02 January 2011

Final received 14 November 2011

Finally accepted 29 December 2011

Citation: Khan, M.M.H. (2012). Population and prey of the Bengal Tiger Panthera tigris tigris (Linnaeus, 1758) (Carnivora: Felidae) and their prey in the Sundarbans, Bangladesh. Journal of Threatened Taxa 4(2): 2370-2380.

Copyright: @ M. Monirul H. Khan 2012. Creative Commons Attribution 3.0Unported License. JoTT allows unrestricted use of this article in any medium for non-profit purposes, reproduction and distribution by providing adequate credit to the authors and the source of publication.

Author Details: The author is a wildlife biologist specializing in research and conservation of tigers. Currently, he serves as Associate Professor of Zoology in Jahangirnagar University, Bangladesh, and his activities include teaching and research on various aspects of wildlife and wildlife habitats.

Acknowledgement: I sincerely acknowledge the financial support from the Save the Tiger Fund, National Fish and Wildlife Foundation, USA. Thanks to the Forest Department of Bangladesh for giving the official permission, and providing the local support, that made the project successful. The Zoological Society of London (ZSL) has provided administrative support, and Sarah Christie, Chris Carbone and Marcus Rowcliffe of ZSL have provided technical support to this project. My sincere thanks to Zahangir Alom and all other field assistants who were an integral part of the fieldwork of this project.
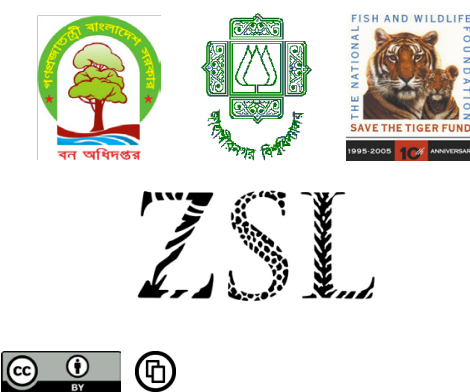

OPEN ACCESS | FREE DOWNLOAD
Abstract: The results from intensive small scale surveys are often difficult to extrapolate to wider spatial scales, yet an understanding at such scales is critical for assessing the minimum densities and populations of rare and wide ranging species. In this paper, the minimum size of population and minimum density estimates of Bengal Tigers Panthera tigris tigris and its prey were conducted from 2005 to 2007 using camera traps for 90 days and using distance sampling surveys for over 200 days, respectively. The results were extrapolated from the core study area in Katka-Kochikhali, southeastern Sundarbans, to five additional sites using indices of abundance. With the use of 10 camera-traps at 15 trap-points, field data provided a total of 829 photos, including seven photos of five individual tigers. A total of 5.0 (SE $=0.98$ ) tigers (adults and sub-adults) are thus estimated in the core area with an estimated density of 4.8 tigers $/ 100 \mathrm{~km}^{2}$. Distance sampling surveys conducted on large mammalian prey species obtained an overall density estimate of 27.9 individuals $/ \mathrm{km}^{2}$ and a biomass density of $1,037 \mathrm{~kg} / \mathrm{km}^{2}$. Indices of abundance were obtained by using tiger track sighting rates (number of tracks $/ \mathrm{km}$ of riverbank) and the sighting rates of the prey species (number of prey/km of riverbank) in the core area and in five additional sites across the region. The densities of tiger tracks and sighting rates of prey were strongly correlated suggesting a wide scale relationship between predator and prey in the region. By combining the estimates of absolute density with indices of abundance, an average of 3.7 tigers $/ 100 \mathrm{~km}^{2}$ across the region is estimated, which given an area of $5,770 \mathrm{~km}^{2}$, predicts a minimum of approximately 200 tigers in the Bangladesh Sundarbans.

Keywords: Camera-trapping, distance sampling, Panthera tigris, prey density, Sundarbans, tiger density track survey.

\section{INTRODUTION}

The Sundarbans of Bangladesh and India is the world's largest tidal mangrove forest (Chaudhuri \& Choudhury 1994; Khan 2002) and represents a region of international importance (Seidensticker 2004). It has been identified as a Level I Tiger Conservation Unit (TCU), because the habitat offers the highest probability of persistence of tiger population in the long term (Wikramanayake et al. 1999) and holds one of the two largest tiger populations globally (Seidensticker et al. 1999; WWF 1999; Khan 2002, 2004a). Because unfragmented mangrove habitat is naturally inaccessible, this region offers a protected environment with the potential for the long-term conservation of tigers.

The Bengal Tiger is catagorized as Endangered globally (Chundawat et al. 2011) and Critically Endangered nationally (in Bangladesh) (IUCNBangladesh 2000). It is listed in the third schedule of the Bangladesh Wildlife Act of 1974, implying its full protection by interdicting killing and capturing (MoEF-Bangladesh 2004).

Despite its importance for tiger conservation, there have been a few studies which have used robust and repeatable methods to estimate the 
abundance of tigers in the region. MoEF-Bangladesh (2004) has reviewed the previous attempts to measure tiger population in Bangladesh and used the pugmark tracking method extensively during 2004. The method used is an extension of the ethnic methods used by tribal and shikaris in India. Mr. Saroj Rai Choudhury (Choudhury 1970, 1972), a forester from Orissa is responsible for scientifically establishing this postulate (MoEF-Bangladesh 2004). A number of practicing wildlife biologists have further intensified its use (Panwar 1979) or have refined the technique (Singh 2000).

Previous attempts to measure tiger population in this area from pugmark censuses or interviews (Hendrichs 1975) have been shown to be unreliable (Karanth et al. 2003; Khan 2004b). Other studies in the region have been based on indirect evidences (Seidensticker \& Hai 1978; Seidensticker 1986, 1987; Tamang 1993; Reza 2000; Khan 2004b) or extrapolations from telemetry studies (Barlow et al. 2009). This paper presents the first estimate of tiger density based on camera-trap surveys in the Bangladesh Sundarbans.

Since tigers depend on large mammalian prey, the population density of large mammals should be assessed in order to understand the carrying capacity and long-term conservation status of tigers (Sunquist 1981; Karanth \& Sunquist 1995; Sunquist et al. 1999). Large mammals including Spotted Deer Axis axis, Wild Boar Sus scrofa and Rhesus Macaque Macaca mulatta together comprise $95 \%$ of the biomass consumed by tigers in the Sundarbans (Khan 2008). This study uses estimates of abundance of these species to make inferences about tiger abundance in the wider region.

Camera-traps are becoming established as one of the major tools in wildlife monitoring (Rowcliffe et al. 2008) and have been extremely effective at monitoring individually marked species like tigers (Karanth \& Nichols 1998; Karanth et al. 2006). However, most camera-trap studies focus on relatively small areas (e.g., typically under $300 \mathrm{~km}^{2}$ ) (Carbone et al. 2001; Karanth et al. 2004). Ideally, we need information on wider spatial scales for wide ranging and rare species. Under such circumstances, it is useful to develop methods to extend camera-trapping results to wider spatial scales through the use of calibrated indices such as track counts (Stander et al. 1997; Stander 1998; Karanth et al. 2003; Stephens et al. 2006).

In this paper I present the results of intensive monitoring in the core study site, using mark-recapture analysis of data collected from camera-traps (Otis et al. 1978; White et al. 1982; Rexstad \& Burnham 1991) and estimates of the main prey species based on distance sampling (Eberhardt 1978; Burnham et al. 1980; Buckland et al. 1993). Then using an indexbased survey of tiger tracks and sightings of their main prey species, I have extended these results to the wider region.

\section{MATERIAL AND METHODS}

\section{Study Area}

The Sundarbans is a mangrove swamp comprising mainly holophytic trees with the average canopy height of less than 10m (Hussain \& Acharya 1994). The forest floor is approximately $0.9-2.1 \mathrm{~m}$ above the mean sea level (Tamang 1993). The Bangladesh Sundarbans covers an area of $5,770 \mathrm{~km}^{2}$, of which $1,750 \mathrm{~km}^{2}$ is covered by rivers and creeks (Hussain \& Acharya 1994). The banks along the shores are cleared by tidal cycles twice per day providing ideal conditions for tiger track counts. All tracks sighted are guaranteed to be relatively fresh (maximum five days) because old tracks are washed away by the tides in about five days.

The study was undertaken across six sites in the Bangladesh Sundarbans, of which three are in wildlife sanctuaries (Sundarbans East, Sundarbans South and Sundarbans West) that form a UNESCO World Heritage Site with a total area of $1,397 \mathrm{~km}^{2}$. The camera-trap survey was conducted in the Sundarbans East Wildlife Sanctuary (total area of $312 \mathrm{~km}^{2}$, between $21^{\circ} 49$ "$\left.21^{0} 56^{\prime \prime} \mathrm{N} \& 89^{\circ} 44^{\prime \prime}-89^{\circ} 52^{\prime \prime} \mathrm{E}\right)$, covering only the southern part of the sanctuary. In five additional sites, and in the core study area, lower intensity monitoring methods based on relative abundance of tiger tracks and prey sightings along the riverbanks were used to assess relative abundance. All of the additional sites were of roughly equal size, approximately $170 \mathrm{~km}^{2}$ (Table 1 and Image 1).

\section{Field study}

The field study was conducted for more than 200 days from October 2005 to January 2007 (camera-trap survey was conducted for 90 days from 06 September to 04 December 2006), but some of the data on prey 




Image 1. The Sundarbans of Bangladesh and India showing six sites where the survey on tiger and prey densities was conducted.

Table 1. Six sites in the Sundarbans where the surveys of tiger and prey densities were conducted (each survey site was approximately $170 \mathrm{~km}^{2}$ )

\begin{tabular}{|c|c|c|c|}
\hline & Name of the site & $\begin{array}{l}\text { Legal } \\
\text { status }\end{array}$ & Geographic location \\
\hline 1 & Katka-Kochikhali & WS & $21^{\circ} 49^{\prime}-21^{0} 57^{\prime} \mathrm{N} \& 89^{\circ} 43^{\prime}-89^{\circ} 51^{\prime} \mathrm{E}$ \\
\hline 2 & Hironpoint & WS & $21^{\circ} 45^{\prime}-21^{0} 52^{\prime} N \& 89^{\circ} 21^{\prime}-89^{\circ} 29^{\prime} E$ \\
\hline 3 & Mandarbaria & WS & $21^{\circ} 38^{\prime}-21^{\circ} 47^{\prime} N \& 89^{\circ} 12^{\prime}-89^{\circ} 18^{\prime} E$ \\
\hline 4 & Harintana & RF & $22^{\circ} 04^{\prime}-22^{0} 11^{\prime} \mathrm{N} \& 89^{\circ} 42^{\prime}-89^{\circ} 49^{\prime} \mathrm{E}$ \\
\hline 5 & Chandpai & RF & $22^{0} 18^{\prime}-22^{0} 25^{\prime} \mathrm{N} \& 89^{\circ} 38^{\prime}-89^{\circ} 47^{\prime} \mathrm{E}$ \\
\hline 6 & Burigoalini & $\mathrm{RF}$ & $22^{\circ} 07^{\prime}-22^{\circ} 15^{\prime} \mathrm{N} \& 89^{\circ} 07^{\prime}-89^{\circ} 15^{\prime} \mathrm{E}$ \\
\hline
\end{tabular}

WS - Wildlife Sanctuary; RF - Reserve Forest

were collected from September 2001 to February 2003. Tigers were identified using their stripe patterns (Schaller 1967; McDougal 1977; Karanth \& Nichols
1998) (Image 2), but Goyal \& Johnsingh (1996) experienced problems in identifying camera-trapped tigers. An analysis of the capture history was used to estimate capture-recapture analysis (Otis et al. 1978; White et al. 1982; Rexstad \& Burnham 1991). This technique as well as others based on the use of cameratrap data has been shown to be effective at extremely low population (Simcharoen et al. 2007; Lynam et al. 2008).

The location of camera-trap points were selected to maximize the chances of obtaining tiger photos, based on the presence of earlier tiger signs (tracks, scats, kills, scrapes, scent deposits, etc.) and the intersections of trails (Karanth \& Nichols 1998). The trap-points were set approximately $2 \mathrm{~km}$ apart, typical of other tiger surveys (Karanth et al. 2004) so that it 

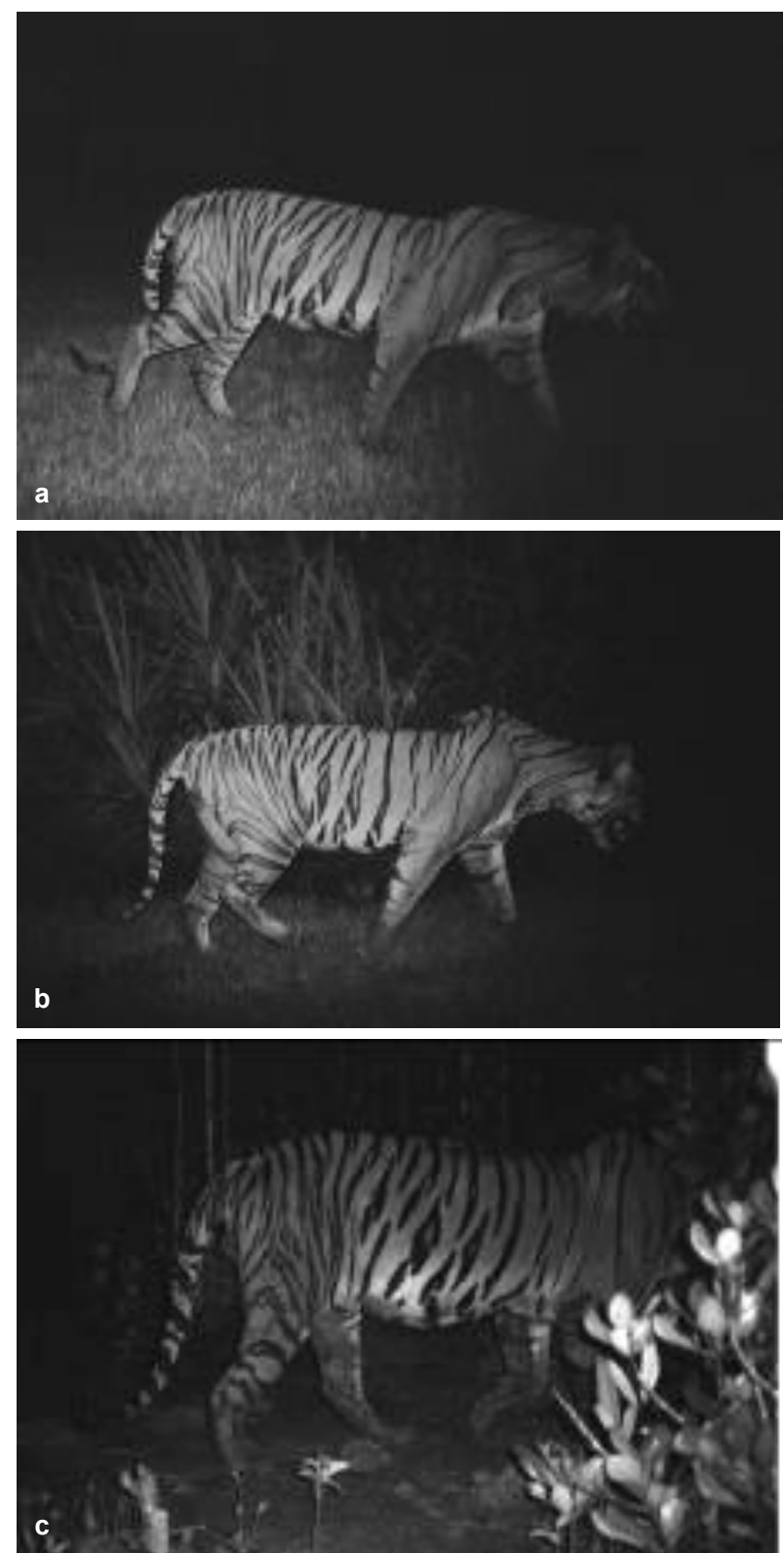

Image 2. Camera-trap photos showing the stripe patterns used in the identification of individual tigers.

a \& b - represent the same tiger; c - represents a different tiger.

was unlikely that any area in the camera-trapping plot had a zero probability of capturing a tiger (Karanth \& Nichols 1998). All trap-points were marked on a map using a GPS unit (eTrex Vista C; accuracy: $\pm 15 \mathrm{~m}$ ). The survey area was surrounded on three sides by large rivers. On the northern side, however, I assumed the survey area included a boundary strip of $2 \mathrm{~km}$, based on the movements of two recaptured tigers which had crossed traps of about $4 \mathrm{~km}$ distance (see Karanth \& Nichols 1998). The total survey area surrounded by the rivers and accounting for the boundary strip in the north was approximately $105 \mathrm{~km}^{2}$ (Image 3 ).

A total of 10 commercially made Wildlife Pro (made by Forestry Suppliers, Inc.; www.forestry-suppliers. com) camera-trap units were used in the survey area. The camera-traps have protective water-proof housing (with camouflaging colouration). Inside the housing there is a Canon Super Shot fully-automatic $35 \mathrm{~mm}$ autofocus camera and a motion sensor for triggering the camera. The camera-traps were mounted on wooden posts or on tree trunks where available, about $350 \mathrm{~cm}$ away from the trail at a height of $45 \mathrm{~cm}$ (Karanth \& Nichols 1998).

During the sampling period (06 September to 04 December 2006) the camera-traps were systematically shifted in three camera-trapping sub-plots (Kochikhali, Katka and Chita Katka) in order to cover all the potential trap-points by limited number of camera-trap units (Image 3). The 90-day (24-hour) survey period, was subdivided into two 45-day phases, occasion 1 (when the photographed individual tigers were identified or 'marked') and occasion 2 (when both 'marked' and 'unmarked' individual tigers were photographed). For each occasion the camera-traps were deployed in three consecutive sub-plots, for 15 days each (Image 3). Cameras were placed in pairs at each trap site in order to get photos of both sides of a tiger. Therefore, each sub-plot contained five trap-points with a total of 15 . See Table 2 for details of photo captures.

Typically for tiger surveys, a maximum of two months is recommended (Karanth et al. 2002), but more time was required in this study because of the limited number of camera-traps and the difficulty of obtaining photographs of tigers. Trapping rates may have been reduced by the absence of obvious trails in the Sundarbans which lowers the chances of predicting their routes of travel. Since the tiger is a relatively long-living and slow-breeding animal (Nowell \& Jackson 1996), I assumed that there was no significant change in the dynamics of tiger population during the 90-day sampling period. The camera-traps were checked once every day in order to record the date and location of each photographic 'capture'.

The capture history data were analysed by using CAPTURE2 software programme (www.mbr-pwrc. usgs.gov) following M0 model since the capture probability for all adult tigers were the same. This software was developed to implement closedpopulation capture-recapture models. Since it was 


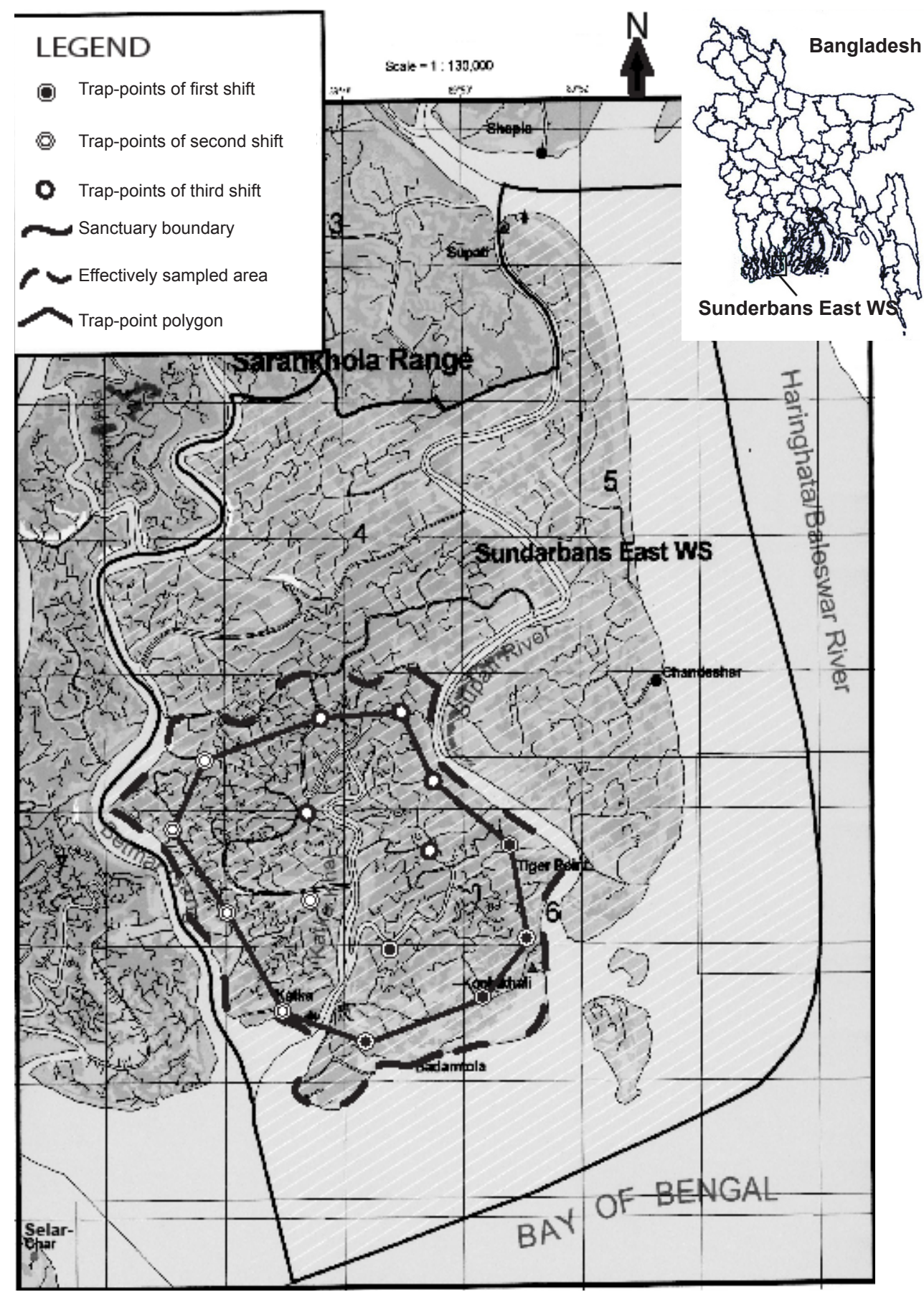

Image 3. The Sundarbans East Wildlife Sanctuary showing 15 trap-points, trap-point polygon and effectively sampled area.

only possible to cover a relatively small part of the Sundarbans with the camera-trap survey, tiger track surveys were used to approximate tiger density over a wider area.

The Sundarbans provides ideal conditions for track surveys because the tidal cycles make it easier to assess new and older tracks. Tigers in this region frequently cross the rivers, especially those that are not very wide.
Thus, track counts represent an estimate of recent tiger activity in the area. Counts along riverbanks were used to estimate the relative density of tigers in the core study area and in each of the additional study plots. Since the tiger tracks are visually identifiable (Van Sickle \& Linzey 1991; Palomares et al. 1996), especially in the muddy riverbanks, all the fresh tracks (maximum five days old; age assessed on the basis 
Table 2. Species captured in camera-trap photos in the Sundarbans East Wildlife Sanctuary.

\begin{tabular}{|l|l|c|c|c|}
\hline & $\begin{array}{l}\text { Species captured in camera-trap } \\
\text { photos }\end{array}$ & $\begin{array}{c}\text { No. of } \\
\text { photos }\end{array}$ & $\begin{array}{c}\text { Total no. of } \\
\text { individuals in photos* }\end{array}$ & $\begin{array}{c}\text { Average no. of } \\
\text { individuals/photo }\end{array}$ \\
\hline 1 & Bengal Tiger Panthera tigris tigris & 7 & 7 & 1 \\
\hline 2 & Human Homo sapiens & 39 & 134 & 3.44 \\
\hline 3 & Spotted Deer Axis axis & 606 & 1,063 & 1.75 \\
\hline 4 & Wild Boar Sus scrofa & 128 & 175 & 1.37 \\
\hline 5 & Rhesus Macaque Macaca mulatta & 10 & 10 & 1 \\
\hline 6 & Lesser Adjutant Leptoptilos javanicus & 8 & 8 & 1 \\
\hline 7 & Red Junglefowl Gallus gallus & 6 & 7 & 1.17 \\
\hline 8 & Greater Coucal Centropus sinensis & 5 & 5 & 1 \\
\hline 9 & House Crow Corvus splendens & 7 & 9 & 1 \\
\hline 10 & Jungle Myna Acridotheres fuscus & 1 & 1 & 1 \\
\hline 11 & Water Monitor Varanus salvator & 12 & 12 & $\mathbf{1 . 7 3}$ \\
\hline & Total/Overall & 829 & $\mathbf{1 , 4 3 1}$ & \\
\hline
\end{tabular}

* It often happened, particularly in case of social animals, that more than one individual was in the photo.

of reference observations of the change of conditions of pugmarks and human footprints with time) were counted from the riverbanks. Wide rivers and narrow creeks present a problem with observation and navigation and thus were not surveyed. The survey took place from a dinghy driven slowly at a relatively constant speed. My field assistants and I searched for fresh tracks on both banks of the river. However, the same track, i.e. the same crossing, on two sides of the river was treated as one observation. Binoculars were used whenever necessary for searching tracks and for general observations. Since the rivers were not straight, the speed of the boat (by using a GPS unit) and the total time of observation were recorded in order to convert the travelling distance into equivalent straight distance.

Sighting rates of track were compared against the density estimate of tigers obtained from camera-traps in Sundarbans East Wildlife Sanctuary to provide a rough calibration between track sighting rates and tiger density. This was then used to extend my estimate of tiger density in the wider region.

The population density of large mammalian prey in the Sundarbans East Wildlife Sanctuary was estimated using distance sampling (Eberhardt 1978; Burnham et al. 1980; Buckland et al. 1993). The transect line length was measured by using a GPS unit. Since the Sundarbans is generally flat, the aerial distance was a close representation of the actual distance covered in line transects. A total of 352 transects of variable lengths was placed that covered a total of $466.8 \mathrm{~km}$ length. The sampling effort was uniform for different seasons of the year. My field assistants and I walked along transects at a roughly uniform speed of $1.3 \mathrm{~km} / \mathrm{h}$ and concentrated on detecting the large mammalian prey at their initial locations. For each observation the sighting distance of the animal (when solitary), or of the centre of the group (when in group), was recorded by using a rangefinder (Bushnell Yardage Pro 800; accuracy: $\pm 1.8 \mathrm{~m}$ ). The sighting angles were recorded by using a compass. The work was mainly conducted in the mornings (0600-1000 h) and afternoons (1500$1900 \mathrm{~h}$ ) when the prey animals were most active and visible. Animal groups were used as the analytical unit since individual data tend to underestimate the true variance (Southwell \& Weaver 1993). DISTANCE 4.0 software (www.ruwpa.st-and.ac.uk/distance) was used to analyse the data derived from line transects to determine the individual density.

The relative densities of large mammalian prey in six sites were estimated by counting them along the two banks of rivers in combination with the counts of tiger tracks. Since the vegetation conditions along the riverbanks were similar, it was assumed that the visibility of prey was uniform. As with the tiger estimates, relative sighting rates at Katka-Kochikhali were used to calibrate a density estimate for the wider area across the remaining five study sites. Sighting rates of large mammalian prey from the river surveys were also made across all six sites and these indices of 
prey abundance were compared against the tiger track sighting rates.

\section{RESULTS}

A total of 829 photographs of different species was obtained from Katka-Kochikhali site during the survey period, of which there were seven photographs (three in occasion 1 and four in occasion 2, with two 'recaptures' in occasion 2) of five individual tigers (Table 2). Using the 'capture' history data in CAPTURE2 software programme it was estimated that the absolute number of tigers (adult and subadult) in the $105 \mathrm{~km}^{2}$ area in the southeastern end of the Bangladesh Sundarbans is $5(\mathrm{SE}=0.96$, capture probability or $\mathrm{p}$-hat $=0.70)$. This means that the tiger density in the area covered by camera-trap survey is 4.8 tigers $/ 100 \mathrm{~km}^{2}$. Due to the complexity and lack of correctness of estimating the variance of estimated area sampled by cameratrapping, the standard error for this density estimate was not calculated. However, due to the fact that the sampled area $\left(105 \mathrm{~km}^{2}\right)$ was very close to $100 \mathrm{~km}^{2}$, it is assumed that the standard error for the density estimate is very close to 0.96 . This is the first estimate of the tiger population density in the Bangladesh Sundarbans that is based on camera-trap survey (Table 3).

Based on tiger track counts the relative density of tigers in six different sites was estimated (Table 4). The average of these six sites represents the average for the entire Bangladesh Sundarbans, which is 0.44 tracks $/ \mathrm{km}$ of riverbank surveyed. The three sites in three sanctuaries clearly had higher densities of tiger tracks than the three sites outside the sanctuaries. The track densities, i.e. relative densities of tigers, were then converted to an estimate of absolute density through extrapolation (Table 4). The average of six sites provides an estimate of 3.7 tigers $/ 100 \mathrm{~km}^{2}$ as an average for the entire area. Since the Bangladesh Sundarbans is an area of $5,770 \mathrm{~km}^{2}$ it is inferred that, to a rounded figure, the total tiger population size would be approximately 200. Assuming that the tiger density in the Indian Sundarbans $\left(4,263 \mathrm{~km}^{2}\right)$ is similar to that in the Bangladesh Sundarbans, we might expect around 150 tigers in the Indian part, forming a single population of around 350 tigers in the entire region.

In Katka-Kochikhali the overall density of large mammalian prey (Spotted Deer, Wild Boar and
Table 3. Individual density and biomass density of tigers and potential prey in the Sundarbans East Wildlife Sanctuary

\begin{tabular}{|l|c|c|c|}
\hline Species & $\begin{array}{c}\text { Average } \\
\text { mass (kg) }\end{array}$ & $\begin{array}{c}\text { Population } \\
\text { density (no./100 } \\
\left.\mathbf{k m}^{2}\right)^{* *}\end{array}$ & $\begin{array}{c}\text { Biomass } \\
\text { density } \\
\left(\mathbf{k g}^{*} / \mathbf{1 0 0} \mathbf{k m}^{2}\right)\end{array}$ \\
\hline Bengal Tiger & 113 & 4.8 & 542 \\
\hline Spotted Deer & 47 & 2090 & 98,230 \\
\hline Wild Boar & 32 & 50 & 1,600 \\
\hline Rhesus Macaque & 4 & 650 & 2,600 \\
\hline
\end{tabular}

*Source: Karanth (1987) for tiger and Karanth \& Sunquist (1992) for prey; ${ }^{* *}$ See Table 4

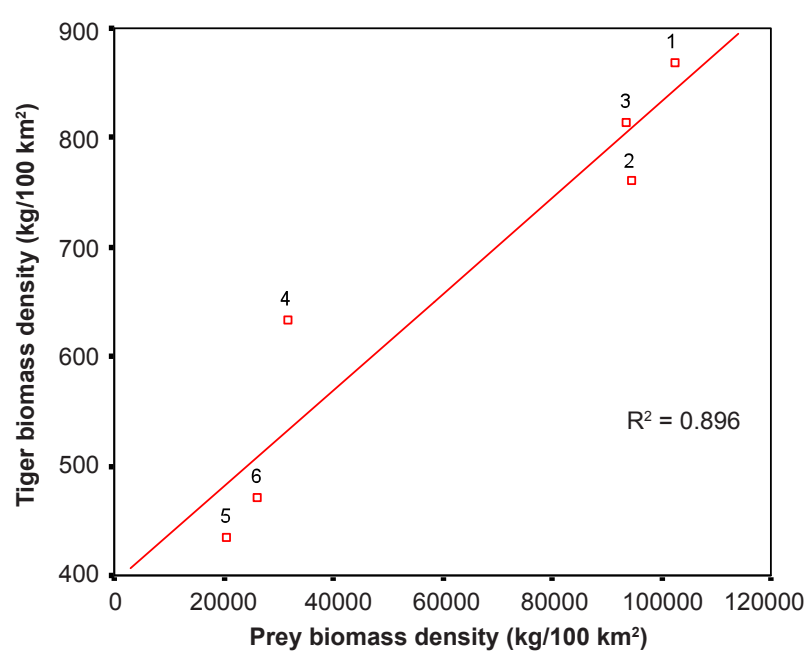

Figure 1. Comparison of tiger and large mammalian prey (spotted deer, wild boar and rhesus macaque) biomass densities $\left(\mathrm{kg} / 100 \mathrm{~km}^{2}\right)$ across six sites (1 - Katka-Kochikhali; 2 - Hironpoint; 3 - Mandarbaria; 4 - Harintana; 5 - Chandpai; 6 - Burigoalini) in the Sundarbans of Bangladesh.

Rhesus Macaque) was estimated at 27.9 large prey/ $\mathrm{km}^{2}$. The average number of large mammalian prey along riverbanks in six sites, i.e., the relative density of prey in the Bangladesh Sundarbans is 4.2 large prey/ $\mathrm{km}$ of riverbank. The relative density was converted to a rough estimate of absolute density, which is 17.3 large prey $/ \mathrm{km}^{2}$ or 1,730 large prey $/ 100 \mathrm{~km}^{2}$. Based on this estimate the total population of three species of large mammalian prey (Spotted Deer, Wild Boar and Rhesus Macaque) in the Bangladesh Sundarbans is inferred at, to a rounded figure of, 99,800.

The absolute densities of tigers and three large mammalian prey in the Bangladesh Sundarbans were converted to biomass densities and were found that it is $542 \mathrm{~kg} / 100 \mathrm{~km}^{2}$ for tigers and $102,430 \mathrm{~kg} / 100 \mathrm{~km}^{2}$ for three large mammalian prey combined (Table 3 ). Therefore, the biomass ratio between tigers and prey is 
Table 4. Tiger and prey population densities (extrapolated) and indices of abundance in the Bangladesh Sundarbans

\begin{tabular}{|c|c|c|c|c|c|c|c|c|c|c|c|c|c|}
\hline & \multirow[t]{2}{*}{$\begin{array}{l}\text { Area sur- } \\
\text { veyed }\end{array}$} & \multirow{2}{*}{$\begin{array}{l}\text { Location in } \\
\text { the } \\
\text { Bangladesh } \\
\text { Sundarbans }\end{array}$} & \multirow[t]{2}{*}{$\begin{array}{l}\text { Legal } \\
\text { status }\end{array}$} & \multicolumn{2}{|c|}{$\begin{array}{l}\text { Water salinity } \\
\quad \text { (ppt) }\end{array}$} & \multicolumn{3}{|c|}{$\begin{array}{l}\text { Relative density of prey } \\
\text { [no. of individuals/km riv- } \\
\text { erbanks }( \pm \mathrm{SE})]\end{array}$} & \multicolumn{3}{|c|}{$\begin{array}{c}\text { Absolute density } \\
\text { of prey } \\
\text { (no. of individuals/ } \\
\text { km²) }^{*}\end{array}$} & \multirow{2}{*}{\begin{tabular}{|c|} 
Relative \\
density of \\
tiger [no. of \\
tracks/km \\
riverbanks \\
$( \pm \mathrm{SE})]$
\end{tabular}} & \multirow{2}{*}{$\begin{array}{c}\text { Absolute } \\
\text { density } \\
\text { of tiger } \\
\text { (no. of } \\
\text { individu- } \\
\text { als/ } 100 \\
\left.\mathbf{k m}^{2}\right)^{*}\end{array}$} \\
\hline & & & & $\begin{array}{c}\text { Dry } \\
\text { season }\end{array}$ & $\begin{array}{c}\text { Wet } \\
\text { season }\end{array}$ & SD & WB & RM & SD & WB & $\mathbf{R M}$ & & \\
\hline 1 & $\begin{array}{l}\text { Katka- } \\
\text { Kochikhali }\end{array}$ & Southeast & \begin{tabular}{|l} 
Wildlife \\
Sanctuary
\end{tabular} & $5-10$ & $0-5$ & $\begin{array}{c}3.97 \\
( \pm 0.80) \\
\end{array}$ & $\begin{array}{c}0.17 \\
( \pm 0.07) \\
\end{array}$ & $\begin{array}{c}2.42 \\
( \pm 0.77) \\
\end{array}$ & 20.9 & 0.5 & 6.5 & $0.58( \pm 0.12)$ & 4.8 \\
\hline 2 & Hironpoint & South & $\begin{array}{l}\text { Wildlife } \\
\text { Sanctuary }\end{array}$ & $20-25$ & $15-20$ & $\begin{array}{c}3.66 \\
( \pm 0.83) \\
\end{array}$ & \begin{tabular}{c|}
0.15 \\
$( \pm 0.06)$ \\
\end{tabular} & $\begin{array}{c}2.36 \\
( \pm 0.81) \\
\end{array}$ & 19.3 & 0.4 & 6.3 & $0.51( \pm 0.14)$ & 4.2 \\
\hline 3 & Mandarbaria & Southwest & $\begin{array}{l}\text { Wildlife } \\
\text { Sanctuary }\end{array}$ & $25-30$ & $20-25$ & $\begin{array}{c}3.62 \\
( \pm 0.87) \\
\end{array}$ & \begin{tabular}{|c|}
0.15 \\
$( \pm 0.07)$ \\
\end{tabular} & $\begin{array}{c}2.40 \\
( \pm 0.69) \\
\end{array}$ & 19.1 & 0.4 & 6.4 & $0.54( \pm 0.15)$ & 4.5 \\
\hline 4 & Harintana & Eastcentral & \begin{tabular}{|l} 
Reserve \\
Forest
\end{tabular} & $5-10$ & $0-5$ & $\begin{array}{c}1.18 \\
( \pm 0.61)\end{array}$ & \begin{tabular}{c|}
0.13 \\
$( \pm 0.07)$ \\
\end{tabular} & $\begin{array}{c}1.18 \\
( \pm 0.59) \\
\end{array}$ & 6.2 & 0.4 & 3.2 & $0.42( \pm 0.17)$ & 3.5 \\
\hline 5 & Chandpai & Northeast & \begin{tabular}{|l} 
Reserve \\
Forest
\end{tabular} & $0-5$ & $0-5$ & $\begin{array}{c}0.76 \\
( \pm 0.39)\end{array}$ & $\begin{array}{c}0.11 \\
( \pm 0.05)\end{array}$ & $\begin{array}{c}0.83 \\
( \pm 0.45) \\
\end{array}$ & 4.0 & 0.3 & 2.2 & $0.29( \pm 0.19)$ & 2.4 \\
\hline 6 & Burigoalini & Northwest & \begin{tabular}{|l} 
Reserve \\
Forest
\end{tabular} & $20-25$ & $5-10$ & $\begin{array}{c}0.96 \\
( \pm 0.42)\end{array}$ & $\begin{array}{c}0.12 \\
( \pm 0.06)\end{array}$ & $\begin{array}{c}0.85 \\
( \pm 0.47)\end{array}$ & 5.1 & 0.4 & 2.3 & $0.32( \pm 0.16)$ & 2.6 \\
\hline Avg & \begin{tabular}{l|} 
Bangladesh \\
Sundarbans
\end{tabular} & & & & & 2.36 & 0.14 & 1.67 & 12.4 & 0.4 & 4.5 & 0.44 & 3.7 \\
\hline
\end{tabular}

RM - Rhesus Macaque; SD - Spotted Deer; WB - Wild Boar; * - Based on the correlation between absolute and relative densities of tiger and prey in Katka-Kochikhali the absolute densities in other five sites were estimated.

1:189. The biomass densities of tigers and prey show strong relationship $\left(\mathrm{R}^{2}=0.896\right)$ across the six sites (Fig. 1).

\section{DISCUSSION}

It is always difficult to estimate the population density of a shy and secretive animal like the tiger, which is thinly distributed throughout a large tract. It is even more difficult in the impenetrable swamp of the Sundarbans where tigers are rarely seen by people. Therefore, most of the previous estimates used pugmark census (Choudhury 1970, 1972; Panwar 1979; Singh 2000) and the figures of tiger population in the Bangladesh Sundarbans (official estimates range from 350 to 450 tigers; MoEF-Bangladesh 2004) are much higher than what is estimated in this study. The scenario is the same in the Indian Sundarbans where, according to the official estimate conducted in 2004, there are 274 tigers (Chowdhury \& Vyas 2005), which is, in the view of present findings, too optimistic. The wide availability of the pugmarks in the Sundarbans (since the ground is soft) gives some the idea that the tiger density is very high, which is not the case (Khan 2004a).

Based on the prey density, and following Karanth \& Stith (1999), and Karanth et al. (2004), there is a previous estimate of tiger density in the Sundarbans East Wildlife Sanctuary (Katka-Kochikhali area is the major part of this Sanctuary) (Khan 2004b) and the estimated figure $\left(4.3\right.$ tigers $\left./ 100 \mathrm{~km}^{2}\right)$ is similar to that estimated in the same area during this study (4.8 tigers $\left./ 100 \mathrm{~km}^{2}\right)$. Notably, it is a well-established fact that carnivores and their prey numbers show strong positive correlation in any undisturbed area (Schaller 1967; Sunquist 1981; Seidensticker \& McDougal 1993; Carbone \& Gittleman 2002; Karanth et al. 2004).

Although there is no previous estimate of tiger density in the Bangladesh Sundarbans based on camera-trap survey, Karanth \& Nichols (2000) reported the tiger density in the Indian Sundarbans, which was based on camera-trap survey. The density $\left(0.84\right.$ tigers $\left./ 100 \mathrm{~km}^{2}\right)$, however, was less than what was found in this study.

The results of radio-collaring two tigresses for a few months in the southeastern Sundarbans in Bangladesh estimated the home range sizes (14.6 and $\left.12.8 \mathrm{~km}^{2}\right)$ is relatively very small, suggesting that the tiger density is very high (Barlow et al. 2009). However, the estimated prey density or other estimates of tiger density in the Sundarbans (Karanth \& Nichols 2000; Khan 2004b; Sharma 2009; Jhala et al. 2011; this study) contradict this implication. In the Indian Sundarbans, one radio-collared tigress was reported to roam in an area of approximately $50 \mathrm{~km}^{2}$ (Sharma 2009), which 
is very different from what was estimated for two radio-collared tigresses in the Bangladesh Sundarbans (Barlow et al. 2009).

Despite some drawbacks, camera-trap survey represents an effective method for surveying tigers. In this study, however, only seven photos of the tiger were obtained, because there were very few or no trail in the Sundarbans that are frequently used by tigers and other wild animals. The forest was very dense and there were limited number of camera-traps.

Because of the tiger's low density and shy nature, other methods of animal population estimation like distance or quadrat sampling (Buckland et al. 1993) are of limited value. Although radiotelemetry-derived data can be used in estimating tiger density (Smith et al. 1987a,b; Quigley 1993), the small number of tagged animals, the presence of untagged animals in the population, and the excessive effort involved in capturing and radio-tracking operations limit the usefulness of this method in tiger density estimation (Karanth 1995).

The ratio of tiger and large mammalian prey biomass densities (1:189) estimated for the Sundarbans is different from those estimated (calculated from tiger and prey densities) for tiger ranges in the neighbouring countries, e.g., 1:342 in Kanha, India (Schaller 1967; Newton 1987), and 1:391 in Chitwan, Nepal (Tamang 1982). This is an indication of insufficient prey for tigers in the Sundarbans (Khan 2008).

The scientific estimate of tiger and large mammalian prey population densities in the Sundarbans that was done in this study will be the key factor in convincing different national and international organisations and communities the potential of the tiger and prey populations in the Sundarbans in the long term. The estimates, however, were largely extrapolations of the absolute densities using indices of abundance. These are not robust estimates, but the indices are correlated between predator and prey, suggesting that they represent a real change in animal abundance across the region (Jhala et al. 2010). The estimates of absolute and relative densities will be useful in temporal monitoring of population trends of tigers and prey in Sundarbans, both inside and outside the sanctuary.

\section{REFERENCES}

Barlow, A.C.D. (2009). The Sundarbans Tiger: Adaptation, population status, and conflict management. $\mathrm{PhD}$ Thesis, University of Minnesota, Minnesota, USA, 191pp.

Buckland, S.T., D.R. Anderson, K.P. Burnham \& J.L. Lake (1993). Distance Sampling: Estimating Abundance of Biological Populations. Chapman and Hall, London, UK, 446pp.

Burnham, K.P., D.R. Anderson \& J.L. Laake (1980). Estimation of density from line transect sampling of biological populations. Wildlife Monographs 72: 1-202.

Carbone, C., S. Christie, K. Conforti, T. Coulson, N. Franklin, J.R. Ginsberg, M. Griffiths, J. Holden, K. Kawanishi, M. Kinnaird, R. Laidlaw, A. Lynam, D.W. Macdonald, D. Martyr, C. McDougal, L. Nath, T. O'Brien, J. Seidensticker, J.L.D. Smith, M. Sunquist, R. Tilson \& W.N.W. Shahruddin (2001). The use of photographic rates to estimate densities of tigers and other cryptic mammals. Animal Conservation 4: 75-79.

Carbone, C. \& J.L. Gittleman (2002). A common rule for the scaling of carnivore density. Science 295: 2273-2276.

Chaudhuri, A.B. \& A. Choudhury (1994). Mangroves of The Sundarbans (Vol. 1-India). IUCN, Bangkok, Thailand, 247pp.

Choudhury, S.R. (1970). Let us count our tiger. Cheetal 14(2): $41-51$.

Choudhury, S.R. (1972). Tiger Census in India. Part I \& II. Cheetal 15(1): 67-84.

Chowdhury, B.R. \& P. Vyas (2005). The Sundarbans. Rupa \& Co., New Delhi, India, 120pp.

Chundawat, R.S., J.A. Khan \& D.P. Mallon (2011). Panthera tigris ssp. tigris. In: IUCN 2011. IUCN Red List of Threatened Species. Version 2011.2. <www.iucnredlist. org >. Downloaded on 09 February 2012.

Eberhardt, L.L. (1978). Transect methods for population studies. Journal of Wildlife Management 42: 1-31.

Goyal, S.P. \& A.J.T. Johnsingh (1996). Problems of identification of camera-trapped tigers. TigerLink News 2(1): 27.

Hendrichs, H. (1975). The status of the tiger Panthera tigris (Linnaeus, 1758) in the Sundarbans Mangrove Forest. Saugetierkunaliche Mittelungen 23(3): 161-199.

Hussain, Z. \& G. Acharya (eds.) (1994). Mangroves of the Sundarbans (Vol. 2-Bangladesh). IUCN, Bangkok, Thailand, 257pp.

IUCN-Bangladesh (2000). Red Book of Threatened Mammals of Bangladesh. IUCN, Dhaka, Bangladesh, 71pp.

Jhala, Y., Q. Qureshi \& R. Gopal (2010). Can the abundance of tigers be assessed from their signs? Journal of Applied Ecology doi: 10.1111/j.1365-2664.2010.01901.x.

Jhala, Y.V., Q. Qureshi, R. Gopal \& P.R. Sinha (eds.) (2011). Status of tigers, co-predators and prey in India, 2010. Report of the National Tiger Conservation Authority, Govt. of India, New Delhi, and Wildlife Institute of India, Dehradun, India, 302pp. 
Karanth, K.U. (1987). Tigers in India: a critical review of field census, pp. 118-132. In: Tilson, R.L. \& U.S. Seal (eds.). Tigers of The World: The Biology, Biopolitics, Management and Conservation of An Endangered Species. Noyes Publications, Park Ride, USA.

Karanth, K.U. (1995). Estimating tiger Panthera tigris populations from camera-trap data using capture-recapture models. Biological Conservation 71: 333-338.

Karanth, K.U., N.S. Kumar \& J.D. Nichols (2002). Field surveys: estimating absolute densities of tigers using capture-recapture sampling, pp. 139-152. In: Karanth, K.U. \& J.D. Nichols (eds.). Monitoring Tigers and Their Prey: A Manual for Researchers, Managers and Conservationists in Tropical Asia. Centre for Wildlife Studies, Bangalore, India.

Karanth, K.U. \& J.D. Nichols (1998). Estimation of tiger densities in India using photographic capture and recaptures. Ecology 79(8): 2852-2862.

Karanth, K.U. \& J.D. Nichols (2000). Ecological Status and Conservation of Tigers in India. Final technical report to the Division of International Conservation, US Fish and Wildlife Service, Washington, DC, and Wildlife Conservation Society, New York, USA; Centre for Wildlife Studies, Bangalore, India, 1-2pp.

Karanth, K.U., J.D. Nichols, N.S. Kumar, W.A. Link \& J.E. Hines (2004). Tigers and their prey: predicting carnivore densities from prey abundance. Proceedings of the National Academy of Sciences of the United States of America 101(14): 4854-4858.

Karanth, K.U., J.D. Nichols, J. Seidensticker, E. Dinerstein, J.L.D. Smith, C. McDougal, A.J.T. Johnsingh, R.S. Chundawat \& V. Thapar (2003). Science deficiency in conservation practice: the monitoring of tiger populations in India. Animal Conservation 6: 141-146.

Karanth, K.U., J.D. Nichols, S. Kumar \& J.E. Hines (2006). Assessing tiger population dynamics using photographic capture-recapture sampling. Ecology 87(11): 2925-2937.

Karanth, K.U. \& B.M. Stith (1999). Prey depletion as a critical determinant of tiger population viability, pp. 100 113. In: Seidensticker, J., S. Christie \& P. Jackson (eds.). Riding the Tiger: Tiger Conservation in Human-dominated Landscapes. Cambridge University Press, Cambridge, UK.

Karanth, K.U. \& M.E. Sunquist (1992). Population structure, density and biomass of large herbivores in the tropical forests of Nagarhole, India. Journal of Tropical Ecology 8: $21-35$.

Karanth, K.U. \& M.E. Sunquist (1995). Prey selection by tiger, leopard and dhole in tropical forests. Journal of Animal Ecology 64(4): 439-450.

Khan, M.M.H. (2002). The Sundarbans, pp. 280-289. In: Gil, P.R. (ed.). Wilderness - Earth's Last Wild Places. CEMEX, Mexico City, Mexico / Conservation International \& Sierra Madre.

Khan, M.M.H. (2004a). Mysterious tigers of the Sundarbans, pp. 94-98. In: Thapar, V. (ed.). Tiger: The Ultimate Guide. CDS Books in association with Two Brothers Press, New
York, USA.

Khan, M.M.H. (2004b). Ecology and conservation of the Bengal tiger in the Sundarbans mangrove forest of Bangladesh. PhD Thesis. University of Cambridge, Cambridge, UK, 297pp.

Khan, M.M.H. (2008). Prey selection by tigers (Panthera tigris) in the Sundarbans East Wildlife Sanctuary of Bangladesh. Journal of the Bombay Natural History Society 105(3): 255-263.

Lynam, A.J., A. Rabinowitz, T.M.M. Myint, K.T. Latt \& S.H.T. Po (2008). Estimating abundance with sparse data: tigers in northern Myanmar. Population Ecology 51: 115121.

McDougal, C. (1977). The Face of the Tiger. Rivington Books, London, UK.

MoEF-Bangladesh (2004). Tiger Census 2004. www.moef.gov. bd/document/Final_TigerCensus_-2004.pdf. Accessed on 01 December 2010.

Newton, P. (1987). The social organization of forest Hanuman Langurs (Presbytis entellus). International Journal of Primatology 8: 199-232.

Nowell, K. \& P. Jackson (1996). Wild Cats: Status Survey and Conservation Action Plan. IUCN, Gland, Switzerland, 382pp.

Otis, D.L., K.P. Burnham, C.G. White \& D.R. Anderson (1978). Statistical inference from capture data on closed populations. Wildlife Monographs 62: 1-135.

Palomares, F., P. Ferreras, J.M. Fedrinai \& M. Delibes (1996). Spatial relationships between Iberian lynx and other carnivores in an area of south-western Spain. Journal of Applied Ecology 33: 5-13.

Panwar, H.S. (1979). A note on tiger census technique based on pugmark tracings. Indian Forester (special issue): 18-36.

Quigley, H.B. (1993). Siberian Tiger. National Geographic 184: 38-47.

Rexstad, E. \& K.P. Burnham (1991). Users Guide for Interactive Program CAPTURE. Colorado Cooperative Fish and Wildlife Research Unit, Fort Collins, USA.

Reza, A.H.M.A. (2000). Ecology of Bengal Tiger, Panthera tigris tigris (Linn. 1758) in the Sundarbans. MSc Thesis. Jahangirnagar University, Dhaka, Bangladesh, 114pp.

Schaller, G.B. (1967). The Deer and the Tiger. University of Chicago Press, Chicago, USA, 384pp.

Seidensticker, J. (1986). Large carnivores and the consequences of habitat insularization: ecology and conservation of tigers in Indonesia and Bangladesh, pp. 1-42. In: Miller, S.D. \& D.D. Everitt (eds.). Cats of the World. Conservation International, Washington DC, USA.

Seidensticker, J. (1987). Managing tigers in the Sundarbans: experience and opportunity, pp. 416-426. In: Tilson, R.L. \& U.S. Seal (eds.). Tigers of the World: The Biology, Biopolitics, Management and Conservation of an Endangered Species. Noyes Publications, Park Ride, USA.

Seidensticker, J. (2004). The Bangladesh Sundarbans as wildife habitat: a look ahead. www.smartoffice.com/Tiger/ Seidensticker.html. Accessed on 01 December 2010. 
Seidensticker, J. \& M.A. Hai (1978). The Sundarbans wildlife management plan: conservation in the Bangladesh coastal zone. Forest Department, Government of the People's Republic of Bangladesh, Dhaka, and WWF, Gland, Switzerland, 129pp.

Seidensticker, J., S. Christie \& P. Jackson (eds.) (1999). Riding the Tiger: Tiger Conservation in Human-dominated Landscapes (Editors' Preface). Cambridge University Press, Cambridge, UK, 383pp.

Seidensticker, J. \& C. McDougal (1993). Tiger predatory behaviour, ecology and conservation. Symposium of the Zoological Society of London 65: 105-125.

Simcharoen, S., A. Pattanavibool, K.U. Karanth, J.D. Nichols \& N.S. Kumar (2007). How many tigers Panthera tigris are there in Huai Kha Khaeng Wildlife Sanctuary, Thailand? An estimate using photographic capturerecapture sampling. Oryx 41(4): 447-453.

Sharma, R. (2009). On the trail of the mangrove monarch. Sanctuary Asia April: 44-47.

Singh, L.A.K. (2000). Tracking Tigers: Guidelines for Estimating Wild Tiger Populations Using the Pugmark Technique. Revised Edition. WWF Tiger Conservation Programme, Delhi, India, 36pp.

Southwell, C. \& K. Weaver (1993). Evaluation of analytical procedures for density estimation from line-transect data: data grouping, data truncation and the unit of analysis. Wildlife Research 20: 433-444.

Smith, J.L.D., C. McDougal \& M.E. Sunquist (1987a). Female land tenure system in tigers, pp. 97-109. In: Tilson, R.L. \& U.S. Seal (eds.). Tigers of the World: The Biology, Biopolitics, Management and Conservation of an Endangered Species. Noyes Publications, Park Ride, USA.

Smith, J.L.D., C. Wemmer \& H.R. Mishra (1987b). A tiger geographic information system: the first step in global conservation strategy, pp. 464-474. In: Tilson, R.L. \& U.S. Seal (eds.). Tigers of the World: The Biology, Biopolitics, Management and Conservation of an Endangered Species. Noyes Publications, Park Ride, USA.

Stander, P.E. (1998). Track counts as indices of large carnivore populations: the relationship between track frequency, sampling effort and true density. Journal of Applied Ecology 35: 378-385.

Stander, P.E., Ghau, D. Tsisaba \& Ui (1997). Tracking and the interpretation of track: a scientifically sound method in ecology. Journal of Zoology 242: 329-341.
Stephens, P.A., O.Y. Zaumyslova, D.G. Miquelle, A.I. Myslenkov \& G.D. Hayward (2006). Estimating population density from indirect sign: track counts and the Formozov-Malyshev-Pereleshin formula. Animal Conservation 9(3): 339-348.

Sunquist, M.E. (1981). Social organization of tigers (Panthera tigris) in Royal Chitwan National Park, Nepal. Smithsonian Contribution to Zoology 336: 1-98.

Sunquist, M.E., K.U. Karanth \& F.C. Sunquist (1999). Ecology, behavior and resilience of the tiger and its conservation needs, pp. 5-18. In: Seidensticker, J., S. Christie \& P. Jackson. Riding the Tiger: Tiger Conservation in Human-dominated Landscapes. Cambridge University Press, Cambridge, UK.

Tamang, K.M. (1982). The status of the tiger (Panthera tigris) and its impact on principal prey populations in the Royal Chitwan National Park, Nepal. PhD Thesis. Michigan State University, Michigan, USA, 184pp.

Tamang, K.M. (1993). Wildlife management plan for the Sundarbans reserved forest. Integrated Resource Development of the Sundarbans Reserved Forest, Bangladesh, Vol. 1, UNDP/FAO project no. BGD/84/056. $113 \mathrm{pp}$.

van Sickle, W.D. \& F.G. Lindzey (1991). Evaluation of a cougar population estimation based on probability sampling. Journal of Wildlife Management 55(4): 738-743.

White, G.C., D.R. Anderson, K.P. Burnham \& D.L. Otis (1982). Capture-recapture and Removal Methods for Sampling Closed Populations. Los Alamos National Laboratory, Los Alamos, USA, 235pp.

Wikramanayake, E.D., E. Dinerstein G. Robinson, K.U. Karanth, A.R. Rabinowitz, D. Olson, T. Matthew, P. Hedao, M. Connor, G. Hemley \& D. Bolze (1999). Where can tigers live in the future? A framework for identifying high-priority areas for the conservation of tigers in the wild, pp. 255-272. In: Seidensticker, J., S. Christie \& P. Jackson (eds.). Riding the Tiger: Tiger Conservation in Humandominated Landscapes. Cambridge University Press, Cambridge, UK.

WWF (1999). Tigers in the Wild: 1999 WWF Species Status Report. WWF, Gland, Switzerland, 31pp.

Justification for delayed publication: Submission of this article to the journal after completion of the fieldwork was delayed because there was an attempt to further enrich the content by inputs from two other carnivore experts, but that ultimately did not work out -- M. Monirul H. Khan. 